ANUVA Volume 1 (2): 71-77, 2017

Copyright (C2017, ISSN: 2598-3040 online

Available Online at: http://ejournal.undip.ac.id/index.php/anuva

\title{
Pengembangan Motif Batik Temanggung Melalui Penguatan Ciri Visual Bertema Kopi
}

\author{
Ana Irhandayaningsih ${ }^{1 *}$ \\ ${ }^{1}$ Program Studi Ilmu Perpustakaan, Fakultas Ilmu Budaya, Universitas Diponegoro, \\ Jl. Prof. Soedarto, SH, Kampus Undip Tembalang, Semarang, Indonesia \\ *) Korespondensi: irhandayaningsih@gmail.com
}

\begin{abstract}
This study aims to develop batik motifs with typical visual ornaments in the form of coffee plants in every motive. To create a more varied batik motifs, this research developed the ornament of leaves and coffee beans from some Temanggung batik especially in the craftsmen "Batik Lumbung". This methods are research development or $R \& D$ (research and Development) with ten (10) stages. Stages performed in this study up to stage six ; problem and potential identification, data collection, product design, design validation, design revisions and product trials. Research data are collected by observation method. Observations made on the development of batik motif Temanggung aims to determine the results of the development of the best batik motif in terms of elements and principles of design. Instrument in this research is observation sheet with scale of list of match (Check List) filled by thirty (30) observer. The results of data collection are analyzed descriptively quantitative based on mean calculation (mean). The result is the development of Temanggung batik motif in terms of design elements and principles in the form of coffee motifs on the blend of color, and the combination of ornament and color is considered good. Form of motifs and isen-isen, the combination of the lines on the overall motif, the blend of colors, as well as a combination of ornaments and color is considered good.
\end{abstract}

Keywords: Batik design, coffee batik pattern, batik Temanggung

\begin{abstract}
Abstrak
Penelitian ini bertujuan untuk mengembangkan motif batik dengan ciri khas ornamen visual berupa tanaman kopi disetiap motifnya. Untuk membuat motif batik yang lebih bervariasi, maka dikembangkan ornamen daun dan biji kopi dari beberapa batik Temanggung khususnya di pengrajin "Batik Lumbung". Penelitian ini termasuk penelitian pengembangan atau R\&D (research and Development) dengan sepuluh (10) tahapan. Tahapan yang dilakukan dalam penelitian ini sampai dengan tahap enam (6), yaitu; potensi dan masalah, pengumpulan data, desain produk, validasi desain,revisi desain dan uji coba produk. Metode pengumpulan data yang digunakan adalah metode observasi. Observasi dilakukan terhadap hasil pengembangan motif batik kopi Temanggung yang bertujuan untuk mengetahui hasil pengembangan motif batik yang terbaik ditinjau dari unsur dan prinsip desain. Instrumen dalam penelitian ini adalah lembar observasi dengan skala daftar cocok (Check List) yang diisi oleh tiga puluh (30) observer. Hasil pengumpulan data tersebut dianalisis secara deskriptif kuantitatif berdasarkan penghitungan ratarata (mean). Hasil jadi pengembangan motif batik Temanggung ditinjau dari unsur dan prinsip desain berupa motif kopi pada aspek perpaduan warna, dan gabungan antara ornamen dan warna dinilai baik. Bentuk motif dan isen-isen, perpaduan antar garis pada keseluruhan motif, perpaduan warna, serta gabungan antara ornamen dan warna dinilai baik.
\end{abstract}

Kata kunci: Motif batik, motif batik kopi, batik Temanggung

\section{Pendahuluan}

Batik adalah salah satu kesenian khas Indonesia yang telah berabad-abad lamanya hidup dan berkembang, serta memiliki nilai-nilai filosofis yang menjadi bagian dari kebudayaan Indonesia khususnya di Pulau Jawa. Secara bahasa, batik berasal dari bahasa Jawa, yaitu amba dan nitik yang 
artinya menuliskan ataumenorehkan titik-titik. Batik merupakan kain bergambar yang dibuat secara khusus dengan cara menuliskan malam pada kain dan pengolahannya diproses dengan cara tertentu.

Kabupaten Temanggung adalah salah satu kota yang memiliki potensi batik yang patut diperhitungkan, yang terkenal dengan nama "Kampoeng" Batik Tegal Temu . Di "Kampoeng" Tegal Temu, membatik telah menjadi bagian dari aktivitas sehari-hari dan menjadi tradisi budaya lokal masyarakat Tegal Temu. Buktinya sekitar 90\% warga Tegal Temu berprofesi sebagai pengrajin batik pada tahun 1675 (Kahumas, 2011).

Secara umum, motif batik di Temanggung terdiri dari berbagai macam flora dan fauna, seperti ikan Unjar, burung merak, kupu-kupu, kembang suruh, dan lain-lain. Motif Unjar menjadi pakem batik khas Temanggung, karena Temanggung ikan tersebut bersifat endemik dan khas. Selain itu, ada pula motif sekar jagad yang merupakan motif berbentuk ceplok berulang yang semuanya saling merapat dan berornamen bunga/tanaman yang banyak dipakai pada batik Sekar. Potensi alam juga menjadi motif batik khas Temanggung, seperti pada batik Tegal Temu yang berupa kopi, tembakau, dan cengkeh. Selain itu hampir semua kain batik tulis Tegal Temu bercorak dasar tidak lepas dari tiga corak tersebut sebagai identitas Temanggung.

Seiring dengan perkembangan zaman, batik Tegal Temu pun mengalami perkembangan dalam segi motifnya, melalui inovasi dan improvisasi, yaitu tanpa meninggalkan motif yang sudah ada dan memunculkan motif-motif baru yang mengikuti perkembangan zaman dan pasar. Dimaksudkan untuk menunjang eksistensi batik Tegal Temu dan permintaan pasar. Hal ini merupakan peluang pasar yang harus dimanfaatkan untuk meningkatkan taraf ekonomi dari pembatik itu sendiri. Peranan masyarakat di Temanggung dalam usaha melestarikan batik Tegal Temu adalah membentuk paguyuban yang dinamakan dengan Paguyuban Batik Tegal Temu pada tanggal 16 April 2008. Ide pembentukan paguyuban ini berasal dari kaum muda Tegal Temu yang memiliki harapan besar kepada kelestarian batik Tegal Temu itu sendiri dan menjadi budaya setempat yang bisa dibanggakan.

Pengukuhan motif kopi sebagai motif khas kabupaten Temanggung membuat potensi batik khas Temanggung semakin meningkat. Motif yang dihasilkan juga tidak terbatas motif kopi. Beberapa motif yang berkembang yaitu motif kupu-kupu,capung, daun, cabe, stroberi, kacang makadamia, singo ulung, tembakau, dan cengkeh. Selain itu minat masyarakat akan kain batik juga makin bertambah dan beberapa anggota masyarakat mulai mendirikan usaha batik.

"Batik Lumbung" merupakan salah satu pengrajin batik yang memproduksi batik khas Temanggung yang berdiri sejak tahun 2012. Pengamatan dilakukan pada hasil lembar observasi pendahuluan motif khas Temanggung yang diproduksi oleh "Batik Lumbung" . Dari kegiatan tersebut didapat bahwa motif khas Temanggung yang diproduksi oleh "Batik Lumbung" tergolong sederhana dan kurang bervariasi atau monoton. Hal ini dikarenakan khususnya kopi agak sulit untuk distilasi, jika dilakukan stilasi maka akan merubah bentuk dasar dan ditakutkan tidak terlihat seperti kopi. Hal ini diungkapkan oleh ibu Sofiah (wawancara pada tanggal 24 November 2014) selaku pengerajin "Batik Lumbung". Bahwa kopi agak sulit untuk dilakukan penggubahan atau stilasi, dan jika terlalu digayakan maka tidak terlihat atau 
tergambar seperti kopi yang sesungguhnya. Sehingga berdasarkan uraian diatas, maka penelitian ini terfokus untuk memberikan atau mencari alternatif agar motif batik khas Temanggung di pengrajin "batik lumbung" yang lebih bervariasi

\section{Metode Penelitian}

Penelitian dan pengembangan atau $R \& D$ (reseach and development) merupakan metode penelitian yang digunakan untuk menghasilkan suatu produk dan menguji keefektifannya. Tahapan yang dilakukan dalam penelitian ini adalah sebagai berikut:

1. Potensi dan Masalah

Potensi pada penelitian ini berangkat dari observasi pendahuluan yang dilakukan oleh peneliti di pengrajin "Batik Lumbung", observasi dilakukan dengan mengamati hasil jadi batik tulis yang ada pada sanggar tersebut.Setelah dilakukan pengamatan timbullah masalah, yaitu motif Temanggung yang digunakan masih sederhana dan belum bervariasi dari segi motifnya, sehingga perlu adanya pengembangan dari segi ornamen utama, ornamen tambahan dan kombinasi isen-isen dalam satu ragam hias.

\section{Pengumpulan data}

Pengumpulan data dilkukan dengan cara peneliti berkunjung ke pengrajin "Batik Lumbung" untuk mendokumentasikan hasil jadi batik khas Temanggung yang diproduksi pada bulan oktober 2014 . Wawancara tak terstruktur juga dilakukan untuk mengetahui tentang batik khas Temanggung yang diproduksi oleh Pengrajin "Batik Lumbung". Selain itu wawancara juga dilakukan untuk mengetahui jenis batik dan warna yang sedang diminati pada saat itu.

\section{Desain Motif}

Setelah data diperoleh, langkah selanjutnya adalah membuat desain motif pengembangan motif batik khas Temanggung sesuai dengan sumber ide motif batik khas Temanggung yang telah dilakukan pemilihan sebelumnya. Setelah dilakukan pemilihan sumber ide, maka dilakukan pembuatan desain motif. Dua desain motif dibuat setiap satu sumber ide sehingga desain motif yang dibuat berjumlah enam desain motif.

\section{Observasi dan Penilaian Motif Batik yang Dihasilkan}

Observasi merupakan pemusatan perhatian terhadap suatu objek dengan menggunakan alat indera penglihatan, pendengaran, dan peraba. Metode pengambilan data ini dilakukan dengan cara melengkapi format pengamatan sebagai instrumen untuk menggali dengan rinci tentang hasil jadi pengembangan warna dan motif batik "Lumbung" khas Temanggung. Jumlah observer berjumlah 30 orang, terdiri dari 3 observer terlatih yaitu praktisi dan pengusaha batik berskala nasional dan 27 observer semi terlatih yaitu mahasiswa yang telah menempuh mata kuliah desain. Instrumen Penelitian Lembar observasi yang digunakan adalah 
lembar observasi yang berisi pengamatan mengenai hasil jadi tiga produk batik khas Temanggung yang diproduksi oleh pengerajin batik "Lumbung" yang telah dimodifikasi warna dan motifnya. Penelitian observasi menggunakan daftar check list $(\sqrt{ })$ sebagai alat pengambilan data. Check list adalah daftar berisi nama-nama subyek dan faktor-faktor yang hendak diteliti dan dimaksudkan untuk mensistematiskan catatan observasi. Penelitian ini berdasarkan "skala likert" dalam Sugiyono (2004: 312), dengan modifikasi empat pilihan yaitu:

1. Sangat Baik : Skor 4, jika pernyataan pada lembar observasi sangat sesuai dengan hasil jadi pengembangan motif batik.

2. Baik : Skor 3, jika pernyataan pada lembar observasi sesuai dengan hasil jadi pengembangan motif batik.

3. Cukup Baik : Skor 2, jika pernyataan pada lembar observasi cukup sesuai dengan hasil jadi pengembangan motif batik.

4. Kurang Baik : Skor 1, jika pernyataan pada lembar observasi kurang sesuai dengan hasil jadi pengembangan motif batik.

Lembar observasi berisi kriteria penilaian untuk setiap aspek motif yang diamati dengan mengacu pada unsur dan prinsip desain serta pengembangan warna dan motifnya.

Penelitian ini menggunakan analisis data deskriptif dengan data kuantitatif. Data mentah yang diperoleh dihitung dengan menggunakan uji nilai rata-rata (mean). Adapun rumus yang digunakan adalah sebagai berikut:

$X=\frac{\sum x t}{N}$

Dimana : $\mathrm{X}$ adalah Nilai rerata, Xt adalah Jumlahan seluruh nilai, dan $\mathrm{N}$ adalah Jumlah Observer

\section{Hasil dan Pembahasan}

Desain motif yang dihasilkan antara lain: 

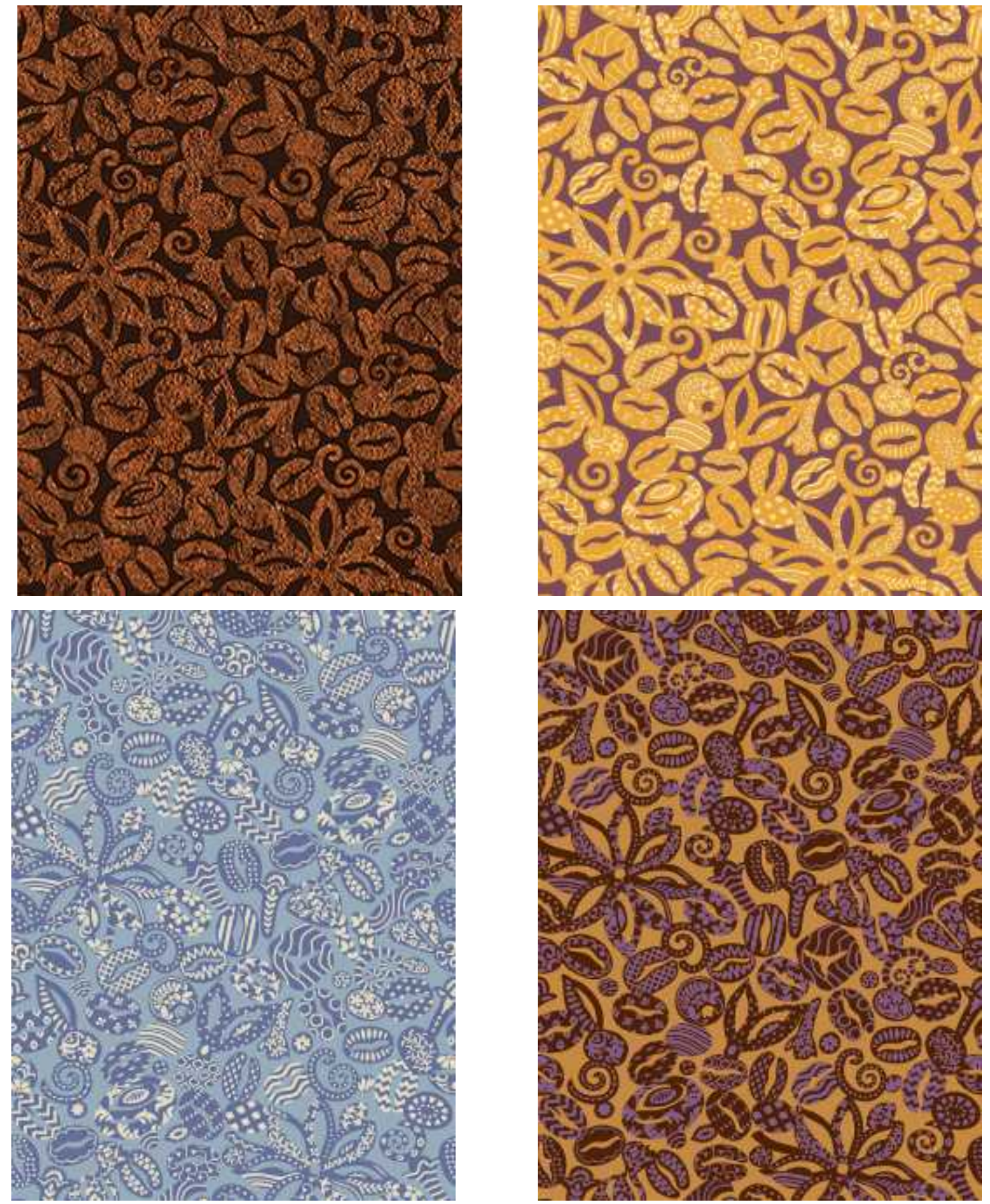

Pengembangan pertama yaitu batik kopi mengalami perubahan desain namun masih masih jelas terlihat secara keseluruhan mengarah keatas dari bagian pinggiran motif batik. Susunan ornamen kopi setelah dikembangkan dibuat lebih renggang dan sedikit berjauhan. Dalam pengembangannya bentuk ujung setiap biji pada ornamen kopi menjadi lebih runcing dan sedikit meliuk. Penambahan batang pada bagian pangkal daun berupa ornamen ukel juga menambah variasi pada motif kopi. Bentuk daun setelah dikembangkan menjadi ornamen dengan bentuk yang lebih besar dan lebih meliuk-liuk. Terdapat pula ornamen daun yang menyerupai ornamen ukel pada bagian ujung daunnya. 
Ukuran yang lebih besar dibandingkan dengan ornamen daun sebelumnya memungkinkan motif batik secara keseluruhan memiliki pusat perhatian atau center of interest. Ornamen tambahan atau disebut juga ornamen pengisi bidang pada motif batik sesudah mengalami pengembangan berupa daun dengan stilasi membentuk ornamen ukel dan motif daun dengan bentuk yang lebih sederhana dan dibuat meliuk. Ornamen tambahan setelah dikembangkan dibuat lebih sederhana dan penempatan ornamen tampak menyatu dengan ornamen utama yaitu biji kopi. Isen-isen pada motif ornamen biji kopi setelah dikembangkan dibuat dengan mengkombinasi tiga jenis isen-isen dalam satu ornamen kopi diantaranya sawut, ceceg dan ceceg pitu. Ornamen kopi setelah dikembangkan dibuat tiga warna sehingga memberi kesan adanya center of interest dalam setiap ornamen kopi. Pada ornamen daun, walaupun hanya diterapkan satu warna dalam satu ornamen, namun jika dilihat secara menyeluruh pada rumpunan ornamen daun terdapat perbedaan warna antara ornamen daun satu dengan yang lain. Jika dilihat warna ornamen daun setelah dikembangkan terdapat ketidakseimbangan penempatan warna, sehingga rumpun daun terlihat kurang harmonis.

\section{Hasil Penilaian Motif Batik}

Hasil penilaian observer mengenai hasil jadi pengembangan batik kopi, terkategori cukup baik.hal ini dikarenakan terdapat tiga aspek unsur dan prinsip desain yang dinilai cukup baik.

1) batik kopi dianggap belum memiliki ukuran dan bentuk yang seimbang sehingga dinilai cukup harmonis dan proporsional,

2) batik kopi dianggap belum menimbulkan irama atau kesan gerak dalam desainnya, dan

3) dianggap sudah memiliki perpaduan warna yang kontras namun belum dilakukan penempatan warna yang baik sebagai suatu penekanan.

Sedangkan jika ditinjau dalam keseluruhan aspek unsur dan prinsip desain hal diatas belum sesuai dengan teori dari Suhersono (2004: 107), untuk membuat desain-desain yang lebih baik maka harus memperhatikan prinsip-prinsip desain dalam menggabungkan unsur-unsur desain.

\section{Simpulan}

Berdasarkan penelitian yang telah dilakukan pada hasil jadi pengembangan motif batik Temangung di pengrajin "Batik Lumbung" dapat ditarik kesimpulan : Hasil jadi pengembangan motif batik Temanggung ditinjau dari unsur dan prinsip desain berupa motif kopi pada aspek perpaduan warna, dan gabungan antara ornamen dan warna dinilai baik. Bentuk motif dan isen-isen, perpaduan antar garis pada keseluruhan motif, perpaduan warna, serta gabungan antara ornamen dan warna dinilai baik. 


\section{Daftar Pustaka}

Depdiknas.2007.Kamus Besar Bahasa Indonesia. Jakarta:Balai Pustaka.

Kamil, Sri Ardianti.1986. Fashion Design. Jakarta:CV.Baru

Prasetya, Joko Tri, dkk. 2009. Ilmu Budaya Dasar. Jakarta: PT Rineka Cipta

Soekarno, dan Lanawati Basuki. 2004. Panduan Membuat Desain Ilustrasi Busana. Jakarta: Kawan Pustaka.

Sugiyono. 2004. Statistika Untuk Penelitian. Jakarta : PT Raja Grafindo Persada

Sugiyono, 2015. Metode Penelitian Pendidikan Pendekatan Kuantitatif, Kualitatif dan R\&D. Bandung: ALFABETA

Suhersono, Hery. 2011. Mengenal Lebih Dalam Bordir Lukis. Jakarta:Dian Rakyat

Susanto, S. K. Sewan. 1980. Seni Kerajinan Batik Indonesia. Jakarta: Balai Penelitian Batik Dan Kerajinan, Lembaga Penelitian Dan Pendidikan Industri. 